\title{
Mucus trails in the rocky intertidal: a highly active microenvironment
}

\author{
Peter Peduzzi, Gerhard J. Herndl \\ Institute of Zoology, University of Vienna, Althanstr. 14, A-1090 Vienna, Austria
}

\begin{abstract}
The significance of mucus trails derived from the herbivorous gastropods Patella caerulea, Monodonta turbinata and Tegula sp. in enhancing microbial activity in marine rocky intertidal and sublittoral zones was investigated by means of microcosm and field experiments. A pronounced increase of bacterial abundance concurrently with extracellular glucosidase activity (alpha-D- and betaD-glucosidase) was observed in mucus-enriched batch cultures within $2 \mathrm{~d}$ of incubation; maximum values of exoproteolytic activity (leucine-aminopeptidase) were reached ca $1 \mathrm{~d}$ later than the peaks in bacterial abundance and glucosidase activity. In all mucus-enriched treatments the levels of glucosidase activity were significantly correlated with bacterial abundance; a high correlation also existed between alpha-D- and beta-D-glucosidase activity in enriched treatments while exoproteolytic activity was less dependent on bacterial density in the later stage of decomposition; this decoupling might be caused by an enhanced aminopeptidase expression per cell. The activity of total glucosidase in the surrounding water closely followed the disappearance of total carbohydrates from mucous layers. Microalgal biomass on glass fiber filters coated with trail mucus was significantly higher $(5.1 \mu \mathrm{g} \mathrm{chl} \mathrm{a}$ $\left.(25 \mathrm{~cm})^{-2}\right)$ after $1 \mathrm{wk}$ of exposure in the field compared to mucus-free control filters $(0.9 \mu \mathrm{g}$ chl a $\left.(25 \mathrm{~cm})^{-2}\right)$. It is hypothesized that mucus-derived polymers entering the DOM-pool are further hydrolyzed and taken up by the free-living bacterial community. The observed stimulation of microalgal growth supports the idea that the breakdown of mucous material by bacterial enzymes can provide a microenvironment enriched in regenerated inorganic nutrients. The estimated high areal trail mucus production $\left(81 \mathrm{~g}\right.$ mucus dry wt $\mathrm{m}^{-2} \mathrm{yr}^{-1}$ for $P$. caerulea, $544 \mathrm{~g}$ mucus dry $\mathrm{wt} \mathrm{m}^{-2} \mathrm{yr}^{-1}$ for $M$. turbinata) suggests that mucus is a significant source for microbial activity in some nearshore waters.
\end{abstract}

\section{INTRODUCTION}

Grazing gastropods are abundant consumers of benthic primary production in many rocky intertidal shores; they can also produce significant amounts of organic detritus either as fecal material or in the form of mucus (Peduzzi \& Herndl 1986, Peduzzi 1987). Secretion of mucus by aquatic animals results in a loss of energy from the organisms and provides a medium for microbial growth (Calow 1974, Herndl \& Velimirov 1986, Horn 1986). Gastropods produce trails of mucus as they crawl, spending up to $80 \%$ of assimilated energy in this process (Edwards \& Welsh 1982, Horn 1986, Davies et al. 1991). Gastropod pedal mucus consists primarily of proteins and polysaccharides with low $\mathrm{C}: \mathrm{N}$ ratios (Connor 1986). In a previous study (Herndl \& Peduzzi 1989) it could be shown that mucous trails produced by marine gastropods are readily degradable and rapidly utilized by microheterotrophs. Rapid structural changes of these mucous layers and loss of total carbohydrates (TCHO) from mucus-coated surfaces (Herndl \& Peduzzi 1989, Peduzzi 1990) may suggest a significant transfer of material and energy to the near surrounding water body.

Bacterial extracellular enzymatic activity has long been recognized as an important factor for macromolecular substrate turnover in marine systems (Hoppe 1983, Vives Rego et al. 1985, Hoppe et al. 1988). Bacteria possess a wide range of extracellular enzymes potentially capable of degrading mucoid polymers which cannot be taken up directly by these organisms unless hydrolyzed. Endohydrolases, acting on particulate material such as mucous layers, generate low molecular weight polymers or oligomers which must still be solubilized by exohydrolases (Priest 1984).

The present study attempted to assess the importance of gastropod-derived mucus as a possible source of nutrients for microbes in the water body near mucus trails. It was asked whether extracellular enzymatic activity in free-living bacteria is stimulated due to the 
presence of mucus and whether the development of enzymatic activity in the waters adjacent to mucus is related to the abundance of suspended bacteria.

In studies by Connor \& Quinn (1984) and Connor (1986), evidence was presented that some herbivorous gastropods produce mucous trails which can stimulate benthic microalgal growth. Although it has been shown that microalgae are able to take up organic nutrients (Hellebust \& Lewin 1977, Myklestad 1978), it is unlikely that they are able to compete efficiently for this organic source with the combined free-living and attached bacterial community. It is more likely that the rapidly colonizing bacteria (Herndl \& Peduzzi 1989, Peduzzi 1990) in concert with bacterivorous flagellates provide a microenvironment enriched in inorganic nutrients. Therefore, it was further asked whether pedal mucus derived from the gastropod species investigated here enhances microphytobenthic growth in natural environments.

Since there is considerable disparity in the limited information available on the quantity of mucus production, the present study also aimed to estimate rates of pedal mucus secretion. Based on these data together with the abundance of animals in the field, we tried to estimate the impact of pedal mucus in sublittoral and intertidal ecosystems inhabited by grazing gastropods.

\section{MATERIAL AND METHODS}

Herbivorous gastropods Patella caerulea and Monodonta turbinata were collected in the intertidal and shallow sublittoral in the Gulf of Trieste (Northern Adriatic Sea) off the Laboratorio di Biologia Marine at Trieste-Aurisina, Italy. Tegula sp. specimens were obtained from the intertidal of 'Pacific Cove', La Jolla, California, USA. All gastropods were kept in aerated aquaria at maximum $24 \mathrm{~h}$ before being used. Laboratory experiments were conducted in the Laboratorio di Biologia Marina at Trieste-Aurisina and at the Institute of Marine Resources, Scripps Institution of Oceanography, UCSD, La Jolla.

Pedal mucus for incubation experiments was collected by allowing the gastropods to crawl for 20 to 30 min on precombusted $\left(450^{\circ} \mathrm{C}\right)$ Whatman $\mathrm{GF} / \mathrm{F}$ glass fiber filters submerged in a sterilized glass tank filled with $0.2 \mu \mathrm{m}$ Nuclepore-filtered seawater. Subsequently, mucus-coated filters were incubated horizontally with the mucus trail facing upward at in situ temperatures (Pacific: $18^{\circ} \mathrm{C}$; Mediterranean: $25^{\circ} \mathrm{C}$ ) in the dark. To each precombusted $\left(470^{\circ} \mathrm{C}\right)$ glass jar, $250 \mathrm{ml}$ of $0.6 \mu \mathrm{m}$ (Nuclepore) filtered seawater, collected from the same site as the gastropods, was added together with 4 to 5 mucus-coated and uncoated (control jar) GF/F filters.
Parameters were monitored in time series over 70 to $100 \mathrm{~h}$ as follows:

(1) Development of bacterial numbers in the incubation media was measured using the acridine orange direct counting (AODC) technique (Hobbie et al. 1977). Water samples were fixed with unbuffered formalin to a final concentration of $2 \%(\mathrm{v} / \mathrm{v})$.

(2) The main purpose of this investigation was to evaluate a possible stimulation of enzymatic action on poly-and oligomers of mucous origin in the water surrounding mucus. In order to estimate bacterial extracellular enzyme activities fluorogenic model substrates were used. The activity of alpha-D-glucosidase and beta-D-glucosidase was measured by means of methylumbelliferyl (MUF) substrates according to Hoppe (1983) and Somville (1984). For protease activity L-leucine-methylcoumarinylamid (leu-MCA) was used (Hoppe 1983, Hoppe et al. 1988). After addition of the substrates to subsamples ( $2.5 \mu \mathrm{M}$ final concentration) withdrawn from the incubation jars at various time intervals, fluorescence intensity of these samples was measured, immediately and usually after 15 to $45 \mathrm{~min}$ of incubation, at $444 \mathrm{~nm}$ under $360 \mathrm{~nm}$ excitation using either a Jasco 820-FP or a Farrand MK2 spectrofluorometer.

(3) Disappearance of total carbohydrates (TCHO) from mucus-coated GF/F filters was determined with the method of Burney \& Sieburth (1977) as described in Herndl \& Peduzzi (1989). TCHO-concentration was selected as a model component for poly-and oligomer liberation from mucous layers. All TCHO-samples were stored frozen $\left(-20^{\circ} \mathrm{C}\right)$ until analyzed.

For each gastropod species mucus incubations were performed in quadruplicate. Two jars were used for determination of bacterial numbers and enzymatic activities, 2 chambers for TCHO-measurements; in each experimental run an additional jar with mucusfree precombusted glass fiber filters served as a control for endogenous microbial growth.

To determine the rate of mucus production by gastropods, 48 Patella caerulea and 65 Monodonta turbinata of average size were allowed to crawl individually on single, preweighed sheets of aluminum foil ( 4 by $4 \mathrm{~cm}$ ) which were held in a tank with aerated seawater in a way that their movement was restricted to the foil. The surface was roughened by crumpling the foils in order to obtain a microstructure similar to natural surface conditions. Foil sheets were replaced every hour over a period of $24 \mathrm{~h}$ to account for possible diurnal variations in movement activity. The foils with pedal mucus trails were rinsed briefly with distilled water to remove salts and ovendried $\left(60^{\circ} \mathrm{C}\right)$ to constant weight. Care was taken that no fecal material remained on the sheets.

A set of experiments was conducted in order to determine whether mucus acts as a microalgal growth 

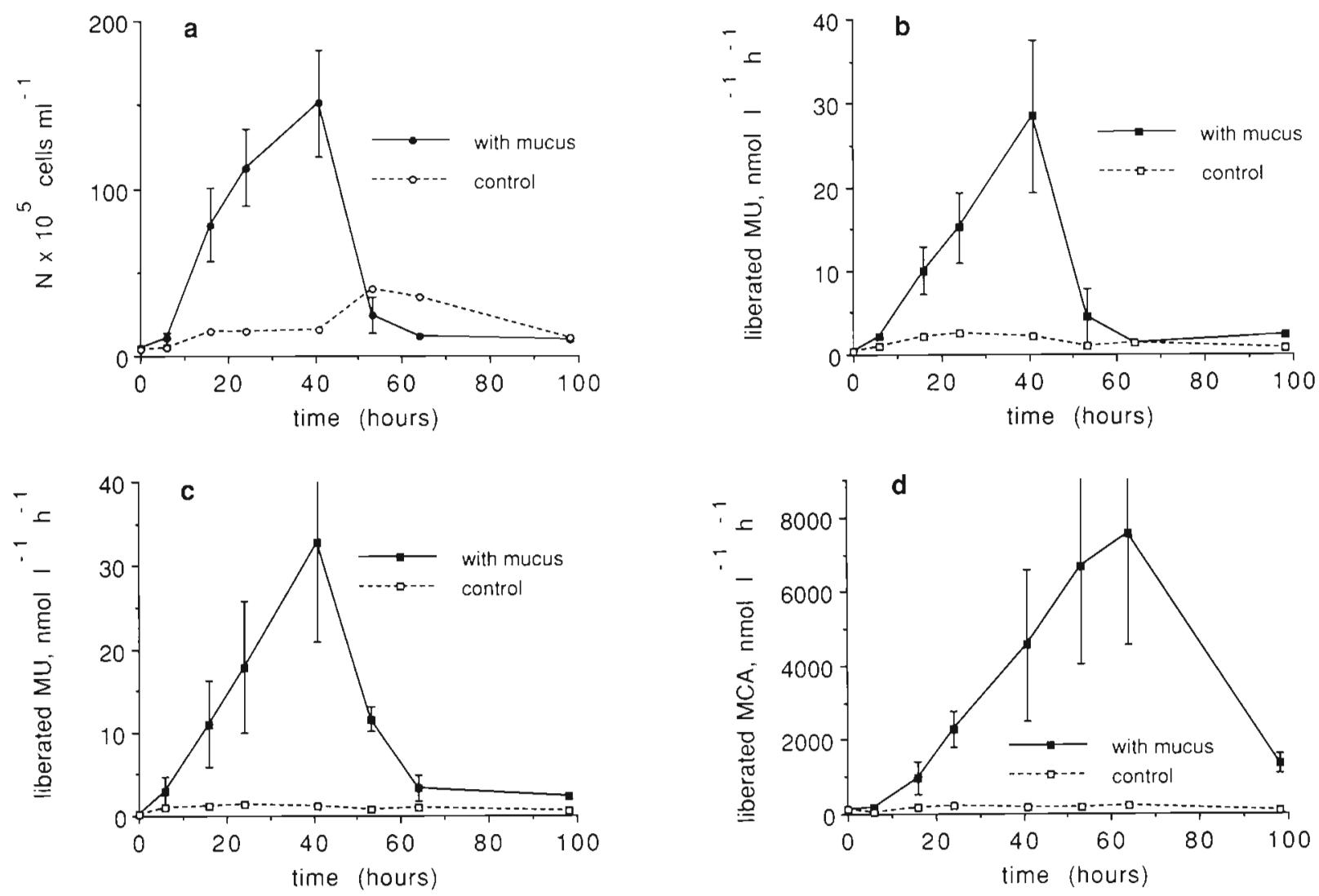

Fig. 1. Batch cultures with trail mucus from Patella caerulea. Development of (a) free-living bacterial abundance, (b) alpha-Dglucosidase activity, (c) beta-D-glucosidase activity and (d) leucin-aminopeptidase activity in $0.6 \mu \mathrm{m}$ filtered seawater incubated with pedal mucus and in a mucus-free control. MU: methylumbelliferone, MCA: methyl-coumarinylamid; vertical bars: \pm 1 SE of the mean

stimulant. For these experiments only Patella caerulea was used as an example of the 3 species studied. This relatively large gastropod produced the highest quantities of mucus and therefore collection of sufficient pedal mucus was substantially facilitated. Single individuals were allowed to crawl on precombusted $\mathrm{GF} / \mathrm{F}$ filters (47 mm diameter) for ca $45 \mathrm{~min}$. Between 10 and 15 glass fiber filters coated with mucus were fixed onto PVC-panels and placed in a horizontal position in the shallow sublittoral (depth: $0.5 \mathrm{~m}$ ) off the laboratory at Aurisina. Equal amounts of uncoated filters were used as a control. To exclude grazing activity and disturbance by animals, cages made of nylon netting (mesh size $3 \mathrm{~mm}$ ) were placed over the panels. A total of 5 experimental runs were conducted, exposing the filters between 180 and $210 \mathrm{~h}$ in the field. The amount of microalgae growing on the filters was measured as chlorophyll a as described in Strickland \& Parsons (1972). Control experiments were conducted in the laboratory to determine whether these mucous layers act as adhesive traps for suspended microalgae (cf. Connor 1986). To exclude the effect of water circulation, filters were placed in flat tanks covered with seawater from the study site and exposed to the same light and temperature conditions as in the field experiments. Although the biomass of microalgae measured as chlorophyll a exhibited a tendency to be higher in field-exposed GF/F filters, no statistically significant differences could be detected (pooled data: $t$-test, $\mathrm{p}>$ $0.2, \mathrm{n}=90$ ). Therefore microalgal biomass on mucuscoated filters in our field experiments was assumed to be mainly caused by algal growth on the surfaces. However, under bloom conditions, which did not occur during our investigation, the effect of gastropod trail mucus as an adhesive trap for microalgae may be significant.

\section{RESULTS}

\section{Development of bacterial numbers and enzymatic activity in surrounding water}

Changes in bacterial abundance in the $0.6 \mu \mathrm{m}$ filtered incubation media with and without the addition of pedal mucus derived from Patella caerulea is shown in Fig. 1. In the enriched treatment, average bacterial density increased from 4.8 to $150.8 \times 10^{5}$ cells ml 

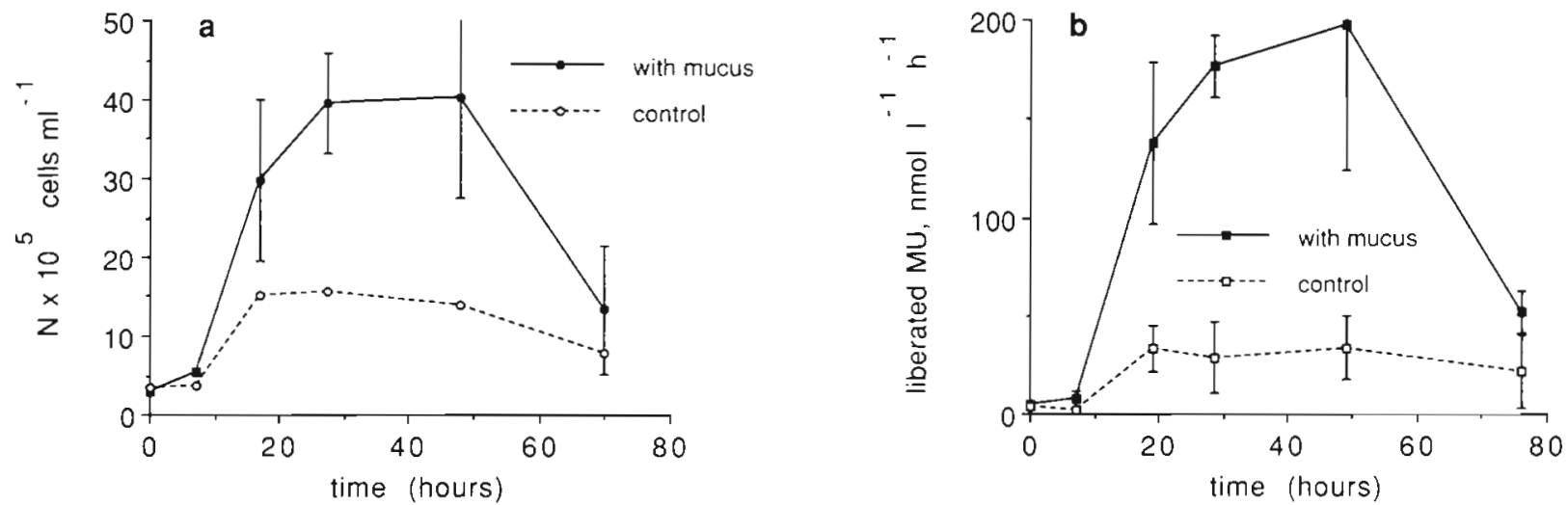

Fig. 2. Batch cultures with trail mucus derived from Monodonta turbinata. Time course of (a) free-living bacterial abundance, (b) total (i.e. alpha-D- plus beta-D-) glucosidase activity in $0.6 \mu \mathrm{m}$ filtered seawater (mucus-enriched and unenriched). Symbols and abbreviations as in Fig. 1
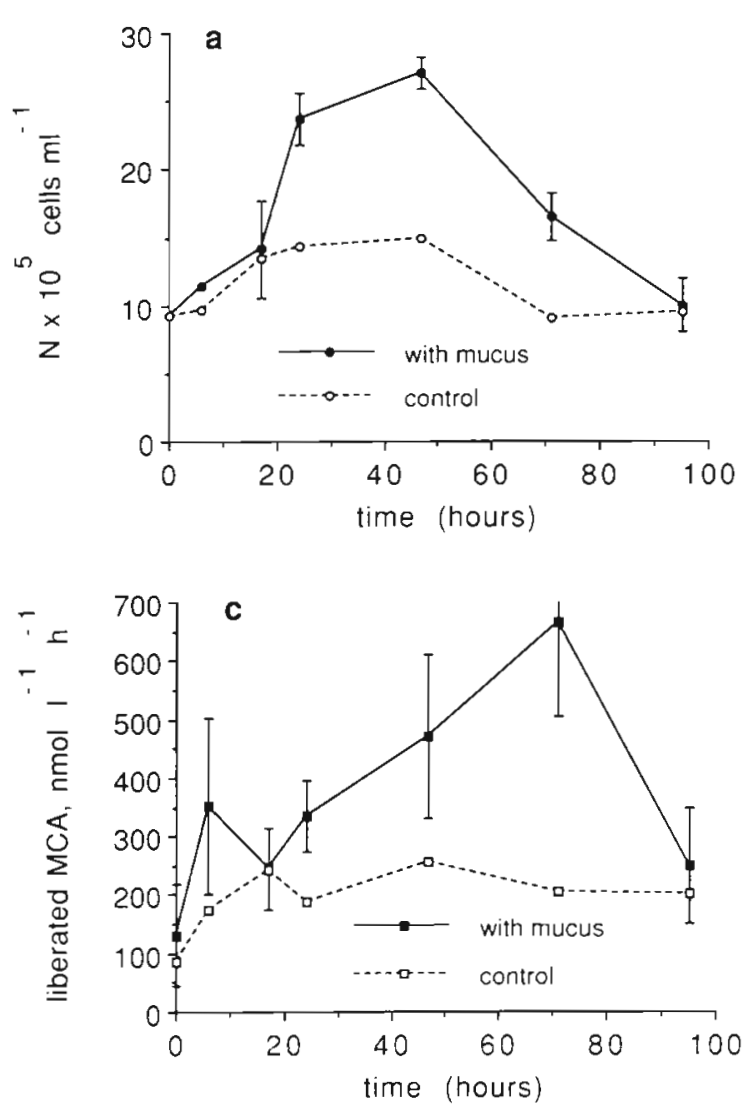

within $41 \mathrm{~b}$ (Fig. 1a). In the mucus-free control chamber bacterial numbers never exceeded $40.3 \times 10^{5}$ $\mathrm{ml}^{-1}$. Concurrently with cell density the activity of extracellular glucosidase (both alpha-D- and beta-Dglucosidase) in the mucus-enriched water increased, reaching peak values also after 41 h of incubation (Fig. 1b, c). The development of exoproteolytic activity exhibited a different pattern (Fig. 1d); maximum values were reached ca $1 \mathrm{~d}$ later than the peaks in bacterial abundance and glucosidase activity.

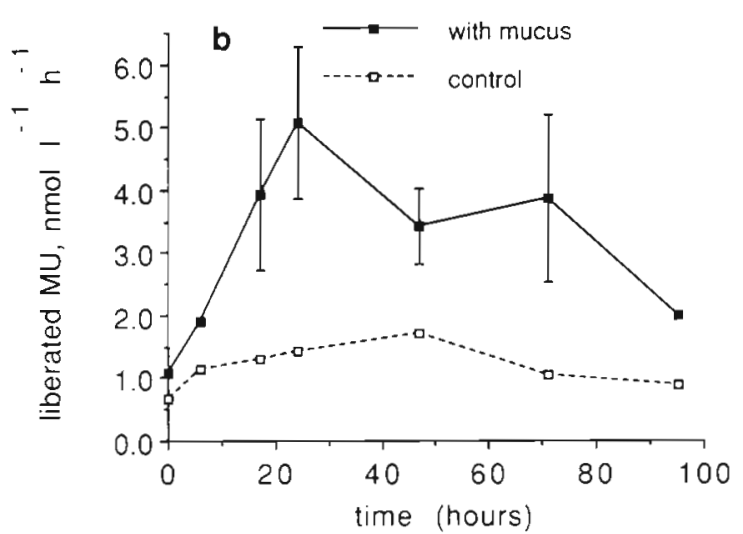

Fig. 3. Batch cultures with pedal mucus obtained from Tegula sp. Development of (a) free-living bacterial density, (b) total glucosidase activity and (c) leucine-aminopeptidase activity in $0.6 \mu \mathrm{m}$-filtered seawater with and without trail mucus. Symbols and abbreviations as in Fig. 1

The reaction of the free-living bacterial community and the extracellular enzymatic activity to addition of mucus derived from Monodonta turbinata and Tegula sp. exhibited a similar pattern to Patella caerulea (Figs. $2 \mathrm{a}, \mathrm{b} \& 3 \mathrm{a}, \mathrm{b})$. Since the activity of beta-D-glucosidase followed the same dynamics as alpha-D-glucosidase during the incubations with mucus in all species studied (as an example see Fig. 1b, c; compare also Table 1), both were summed and presented as total glucosidase activity'. In Fig. 3c the exoproteolytic activ- 
Table 1. Calculated relationships between various microbial parameters measured during decomposition of gastropod pedal mucus. AGA: alpha-D-glucosidase activity; BD: bacterial density; BGA: beta-D-glucosidase activity; LAPA: leucin-aminopeptidase activity; TCHOdis: \% total carbohydrates disappeared from mucous layers; TGA: total glucosidase activity. Units for extracellular enzymatic activity in nmol liberated substrate $l^{-1} h^{-1} ; n=$ number of pairs, $r=$ correlation coefficient, $p=$ probability

\begin{tabular}{|c|c|c|c|c|}
\hline Relationship & Equation & $\mathrm{n}$ & $\mathrm{r}$ & $\mathrm{p}$ \\
\hline \multicolumn{5}{|l|}{ Patella caerulea } \\
\hline $\mathrm{BD}$ vs $\mathrm{AGA}$ & $\mathrm{AGA}=-0.4049+0.1672 \mathrm{BD}$ & 16 & 0.93 & $<0.001$ \\
\hline $\mathrm{BD}$ vs $\mathrm{BGA}$ & $\mathrm{BGA}=1.0349+0.1827 \mathrm{BD}$ & 16 & 0.88 & $<0.001$ \\
\hline$A G A$ vs $B G A$ & $\mathrm{BGA}=1.2395+1.1220 \mathrm{AGA}$ & 16 & 0.97 & $<0.001$ \\
\hline BD vs LAPA & $\mathrm{LAPA}=2735.6+4.3712 \mathrm{BD}$ & 16 & 0.08 & $>0.200$ \\
\hline TCHOdis vs TGA & $-^{a}$ & - & - & - \\
\hline \multicolumn{5}{|l|}{ Monodonta turbinata } \\
\hline$B D$ vs $A G A$ & $\mathrm{AGA}=5.2296+2.2313 \mathrm{BD}$ & 12 & 0.73 & $<0.010$ \\
\hline $\mathrm{BD}$ vs $\mathrm{BGA}$ & $\mathrm{BGA}=-8.4223+2.3748 \mathrm{BD}$ & 12 & 0.88 & $<0.001$ \\
\hline AGA vs BGA & $\mathrm{BGA}=12.1910+0.5794 \mathrm{AGA}$ & 12 & 0.65 & $<0.050$ \\
\hline BD vs LAPA & $-^{a}$ & - & - & - \\
\hline TCHOdis vs TGA & $\mathrm{TGA}=2.0074 \times 10^{2.2445 \mathrm{e}^{- \text {वTCHOdas }}}$ & 10 & 0.99 & $<0.001$ \\
\hline \multicolumn{5}{|l|}{ Tegula sp. } \\
\hline$B D$ vs $A G A$ & $A G A=-2.0600+3.1370 \log (B D)$ & 14 & 0.77 & $<0.010$ \\
\hline $\mathrm{BD}$ vs $\mathrm{BGA}$ & $\mathrm{BGA}=-2.4089+3.2603 \log (\mathrm{BD})$ & 14 & 0.77 & $<0.010$ \\
\hline AGA vs BGA & $\mathrm{BGA}=-0.1431+0.9661 \mathrm{AGA}$ & 14 & 0.94 & $<0.001$ \\
\hline BD vs LAPA & LAPA $=111.62+11.412 \mathrm{BD}$ & 10 & 0.53 & $>0.100$ \\
\hline TCHOdis vs TGA & $\mathrm{TGA}=1.2046 \times 10^{90017 \mathrm{e}^{-3 \text { TCHOAx }}}$ & 8 & 0.99 & $<0.001$ \\
\hline
\end{tabular}

ity is shown for Tegula sp.; a maximum was reached $71 \mathrm{~h}$ after starting the incubation. Unfortunately, no data are available for $M$. turbinata. In all control treatments (precombusted filters only) the parameters investigated remained at low levels.

Based on our data, regression equations were calculated to determine possible correlations and interdependences (Table 1). Throughout all mucusenriched treatments the levels of glucosidase activity were significantly correlated with the density of bacterial cells. A high correlation existed also between alpha-D- and beta-D-glucosidase activity in incubations with mucus from all 3 species. No significant correlation was detected between bacterial density and exoproteolytic activity

\section{Disappearance of total carbohydrates (TCHO) from mucous layers}

Approximately $78 \%$ of the TCHO derived from mucous trails produced by Monodonta turbinata had disappeared ca 40 to $50 \mathrm{~h}$ after starting the incubation (Fig. 4). This $78 \%$ represents the maximum level of mucus TCHO disappearance observed in our experiments. This pattern was followed closely by the activity of total glucosidase in the surrounding water during the first

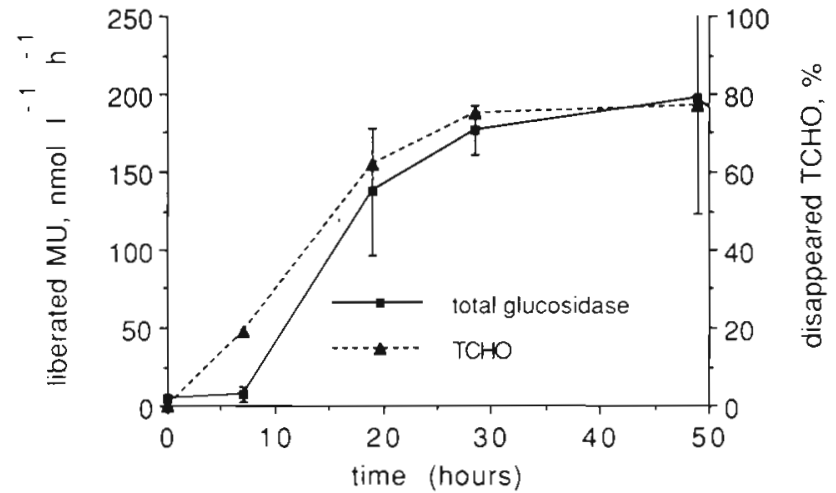

Fig. 4. Incubation with pedal mucus derived from Monodonta turbinata. Disappearence of total carbohydrates (TCHO; per cent of initial) from mucous layers and increase in total glucosidase activity during the first $50 \mathrm{~h}$ of incubation in $0.6 \mu \mathrm{m}$ filtered seawater surrounding mucus trails. Symbols and abbreviations as in Fig. 1

$50 \mathrm{~h}$ as indicated by a highly significant correlation resulting in an exponential regression equation (see Table 1. Using pedal mucus from Tegula sp., ca $76 \%$ of TCHO disappeared even after only $24 \mathrm{~h}$ of incubation (data not shown). Again, the activity pattern of total glucosidase in the surrounding water was closely related to the amount of surface-disappeared TCHO (see equation and correlation parameters in Table 1). 


\section{Growth stimulation of benthic microalgae by pedal mucus}

In all experimental runs, the microalgal biomass on GF/F filters coated with trail mucus from Patella caerulea and exposed in the field was significantly higher at the end of the incubation period ( 7.5 to $8.75 \mathrm{~d}_{\text {i }}$ pooled data: $t$-test, $\mathrm{p}<0.001)$. Normalizing the values to a period of $1 \mathrm{wk}$ field exposure resulted in an average net biomass increase of $5.10 \mu \mathrm{g} \mathrm{chl} \mathrm{a}(\mathrm{SD}=2.41$ ) $25 \mathrm{~cm}^{-2}$ mucus-coated filter area $\mathrm{wk}^{-1}$ as compared to $0.87 \mu \mathrm{g} \mathrm{chl} \mathrm{a}(\mathrm{SD}=0.32)$ on an equal area of mucusfree control glass fiber filters. When checking subsamples under the microscope, only diatoms were found which were therefore considered the main microalgal colonizers of the filters.

\section{Production rates of gastropod pedal mucus}

Since no consistent diurnal pattern of pedal mucus production was detectable from our hourly measurements the data were pooled to give an estimate of mucus secretion on a daily basis. The dry wt of trail mucus produced by an average sized Patella caerulea was $12.27 \mathrm{mg}$ ind..$^{-1} \mathrm{~d}^{-1}(\mathrm{SD}=3.14) ;$ Monodonta turbinata secreted $5.58 \mathrm{mg}$ dry wt ind. ${ }^{-1} \mathrm{~d}^{-1}(\mathrm{SD}=2.26)$; this corresponded to $1.35 \mathrm{mg}$ mucus-TCHO ind.-1 $\mathrm{d}^{-1}$ for $P$. caerulea and $0.55 \mathrm{mg}$ mucus-TCHO ind.$^{-1} \mathrm{~d}^{-1}$ for M. turbinata.

\section{DISCUSSION}

Microbial abundance and extracellular activity measured in our incubation experiments with gastropod pedal mucus exhibited a clear tendency. In all incubation chambers containing mucus-coated glass fiber filters growth of bacteria and extracellular enzymatic activity in the surrounding water body was significantly enhanced when compared to unenriched controls. In $0.6 \mu \mathrm{m}$ filtered seawater $\left(25^{\circ} \mathrm{C}\right)$ enriched with trail mucus derived from Patella caerulea, free-living bacteria grew with a turnover time of $4.0 \mathrm{~h}$; in incubations with mucus from Monodonta turbinata a generation time of $5.1 \mathrm{~h}$ can be calculated during the exponential growth phase. This is in agreement with results obtained in a previous work with mucus produced by M. turbinata (Herndl \& Peduzzi 1989). Generation times determined for free-living bacteria incubated with mucus from Tegula sp. were substantially higher $(17.7 \mathrm{~h})$, indicating a less favorable substrate for bacterial growth derived from this type of mucus. However, the lower temperature in incubations with this Pacific species $\left(18^{\circ} \mathrm{C}\right.$ ) could also have been responsible for the higher generation times. Based on our regres- sion analyses (Table 1) in water surrounding mucus, glucosidase activity can be considered a function of bacterial abundance and appeared to be most likely associated with the free-living bacteria themselves. This was also pointed out by Somville (1984) and Chrost (1989) studying glucosidase activities in natural waters. Furthermore the highly significant correlation between alpha-D- and beta-D-glucosidase activity in all mucus-enriched incubations indicates a close coupling in hydrolyzation of both alpha- and beta-bound polysaccharides of mucus origin. Beta-/alpha-glucosidase ratios varied among the different types of mucus in a range between 0.6 and 1.1 possibly reflecting different carbohydrate composition of the organic substrate (see also Somville 1984).

The interdependence between bacterial abundance and exoproteolytic activity measured as leucinaminopeptidase activity in mucus-enriched incubations was different to that found for glucosidase activity; rather, bacterial numbers and aminopeptidase activity were not significantly correlated over the entire incubation period (Table 1). Although aminopeptidase activity increased during the first part of the incubation concurrently with bacterial numbers, this increase continued during the following day even after the drop in bacterial abundance (see Figs. 1a, d \& 3a, c). There are at least 2 possible explanations for this observation. Although it is strongly suggested that proteolytic activity in natural waters is bound to the envelopes of bacteria (Hollibaugh \& Azam 1983, Vives Rego et al. 1985, Rosso \& Azam 1987), a varying fraction can be found in the dissolved state $(<0.2 \mu \mathrm{m})$ with a considerably increasing percentage in the declining phase of enrichment cultures (Vives Rego et al. 1985). The latter authors argued that no free bacterial proteases are produced, but that in most cases this fraction is due to cell envelope fragments produced upon lysis of cells during the breakdown phase of the population and thus passing $0.2 \mu \mathrm{m}$ filtration. On the other hand it can be assumed that per cell activity of aminopeptidase was enhanced during the decline of cell density. Based on recent findings that low concentrations of hexoses induce glucosidase activity (Chrost 1989), one can speculate that in the advanced phase of our incubations easily assimilable $\mathrm{N}$-sources (amino acids) fell below a critically low level, due to their rapid uptake by microheterotrophs, thus inducing elevated enzyme expression (see also Albertson et al. 1990). Only when the bacterial abundance in the incubation had declined to the initially low levels (e.g. after $64 \mathrm{~h}$ in the incubation with Patella caerulea mucus) did the level of aminopeptidase activity also start to drop.

An additional indication that the free-living bacterial community grows at the expense of pedal mucus is the observed close relationship between disappearance of 
total carbohydrates from the mucous trails and increase in total glucosidase activity in the incubation media. There is evidence in the literature that the products of extracellular hydrolyzation of macromolecules are only partly taken up by microheterotrophs cleaving the substrate (Hoppe 1983); endohydrolases may chop the polymers at random, thereby acting in a loose hydrolysis-uptake coupling. We hypothesize that a significant portion of the pedal-mucus-derived material is solubilized and enters the DOM pool by diffusion, thus being accessible to the free-living bacterial population. Dissolved polymers and oligomers may be further hydrolyzed to monomers or small oligomers by the action of exohydrolases. This is supported by several recent studies which conclude that attached bacteria grow too slowly to account for the observed decomposition of organic material (Kirchman \& Mitchell 1982, Ducklow et al. 1985, Peduzzi \& Herndl 1991). In another study it was found that in the presence of marine snow freeliving bacteria responded rapidly with elevated growth, suggesting that marine-snow-derived DOM becomes available to free-living bacteria, while concurrently the monomeric carbohydrate concentrations remained within the range of controls without marine snow (Herndl 1988). Since it is well documented that monomers do not accumulate in the water, a tight hydrolysis-uptake system in the free-living bacterial community can be assumed (Chrost 1989).

A stimulatory effect in the mucus-associated microenvironment is further documented by the increased microalgal biomass on trail mucus exposed for several days. The ability of mucous trails to stimulate microalgal growth as found in our experiments has also been reported for limpets (Connor \& Quinn 1984, Connor 1986). These authors speculated whether the degree of stimulation is linked to the amount of energy invested in mucus production and to the ability of the animals to utilize the enhanced microalgal production as food source. Our results support the idea that the breakdown of mucus material by bacterial enzymes can provide a microenvironment enriched in nutrients favorable for microalgal production. The resulting elevated algal biomass might be grazed by herbivorous gastropods, thus returning a part of the energy expended for mucus production to the animal (see also Connor \& Quinn 1984, Connor 1986). This stimulation of the growth of the animal's own food source may provide another example of the 'gardening'-concept introduced by Hylleberg (1975). Similar interactions between zoobenthos and microorganisms have been proposed to be highly important in marine benthic environments (Gerlach 1978, Connor et al. 1982, Reise 1983).

Although mucus production rates of neither Patella Caerulea nor Monodonta turbinata varied significantly over a 24 h cycle, a tendency could be observed towards higher secretion during night-time. This might be due to enhanced locomotory activity at night which was also documented in other studies with $M$. turbinata (Wieser \& Dalla Via 1982) and Patella vulgata (Hawkins \& Hartnoll 1983). Based on preliminary estimations concerning the abundance of $P$. caerulea (18 ind. $\mathrm{m}^{-2} ; \mathrm{SE}=11$ ) and $M$. turbinata (267 ind. $\mathrm{m}^{-2} ; \mathrm{SE}=174$ ) in the study area (Gulf of Trieste; unpubl. data), ca $81 \mathrm{~g}$ mucus dry wt $\mathrm{m}^{-2} \mathrm{yr}^{-1}$ may be produced by $P$. caerulea and $544 \mathrm{~g}$ mucus dry wt $\mathrm{m}^{-2} \mathrm{yr}^{-1}$ by $M$. turbinata. Rearranging values reported in the literature, our calculated values appear to be somewhat high. Crude estimates given by Paine (1971) for e.g. Tegula funebralis yielded $13.8 \mathrm{~g}$ mucus dry wt $\mathrm{m}^{-2} \mathrm{yr}^{-1}$; only $2.55 \mathrm{~g}$ mucus dry wt $\mathrm{m}^{-2} \mathrm{yr}^{-1}$ was reported for $P$. vulgata (Wright \& Hartnoll 1981). Despite the fact that our provisional annual mucus production values may represent maximum rates since they are based on measurements conducted at summer temperatures, more recent studies indicate that pedal mucus production by gastropods was substantially underestimated in earlier studies. For example, in the above-cited work with $P$. vulgata (Wright \& Hartnoll 1981) mucus secretion was estimated at only $4 \%$ of ingested energy; this may be erroneous as demonstrated in a more recent study in which the mucus term in the energy budget for $P$. vulgata was determined at about $40 \%$ of ingestion (Davies et al. 1991). Our pedal mucus production estimates per individual per day are within the same order of magnitude as values in another recent work (Horn 1986) on Chiton pelliserpentis.

We have demonstrated that gastropod trail mucus secreted in rocky intertidal and sublittoral shores can provoke significant microbial activity. A distinct temporal distribution of extracellular enzyme activity can be assumed leading to a tight hydrolysis-uptake coupling in the mucus-surrounding microenvironment. It seems evident that mucus release can be of significant importance for microbial (autotrophic and heterotrophic) productivity in nearshore waters with abundant gastropod biomass.

Acknowledgements. The hospitality of the Stazione Biologia Marina at Trieste-Aurisina and of F. Azam (Institute of Marine Resources, Scripps Institution of Oceanography, UCSD, La Jolla, California) are gratefully acknowledged. We thank J. A. Ott for laboratory space and valuable discussions. Special thanks are due to F. Starmühlner for making this study possible. This work was supported by the Austrian Science Foundation projects numbers P 7009 to P.P. and P 6695 to G.J.H.

\section{LITERATURE CITED}

Albertson, N. H., Nyström, T., Kjelleberg, S. (1990). Exoprotease activity of two marine bacteria during starvation. Appl. environ. Microbiol. 56: 218-223 
Burney, C. M., Sieburth, J. M. (1977). Dissolved carbohydrates in seawater. II. A spectrophotometric procedure for total carbohydrate analysis and polysaccharide estimation. Mar Chem. 5: 15-28

Calow, P. (1974). Some observations on locomotory strategies and their metabolic effects in two species of freshwater gastropods, Ancylus fluviatilis Müll. and Planorbis contortus Linn. Oecologia (Berl.) 16: 149-161

Chrost, R. J. (1989). Characterization and significance of $\beta$ glucosidase activity in lake water. Limnol. Oceanogr. 34: $660-672$

Connor, M. S., Teal, J. M., Valiela, I. (1982). The effect of feeding by mud snails, Ilyanassa obsoleta (Say), on the structure and metabolism of a laboratory benthic algal community. J. exp. mar Biol. Ecol. 65: 29-45

Connor, V M. (1986). The use of mucous trails by intertidal limpets to enhance food resources. Biol. Bull. mar. biol. Lab., Woods Hole 171: 548-564

Connor, V M., Quinn, J. F. (1984). Stimulation of food species growth by limpets mucus. Science 225: 843-844

Davies, M. S., Hawkins, S. J., Jones, H. D. (1991). Mucus production and physiological energetics in Patella vulgata L. J. Mollusc. Stud. 56: 499-503

Ducklow, H. W., Hill, S. M., Gardner, W D. (1985). Bacterial growth and the decomposition of particulate organic carbon collected in sediment traps. Cont. Shelf Res. 4: 445-464

Edwards, S. F., Welsh, B. L. (1982). Trophic dynamics of a mud snail (Ilyanassa obsoleta (Say)) population on an intertidal mudflat. Estuar. coast. Shelf Sci. 14: 663-686

Gerlach, S. A. (1978). Food-chain relationships in subtidal silty sand marine sediments and the role of meiofauna in stimulating bacterial productivity. Oecologia (Berl.) 33: 55-69

Hawkins, S. J., Hartnoll, R. G. (1983). Grazing of intertidal algae by marine invertebrates. Oceanogr. mar Biol. Ann. Rev. 21. 195-282

Hellebust, J. A., Lewin, J. (1977). Heterotrophic nutrition. In: Werner, D. (ed) The biology of diatoms. University of California Press, Berkeley, p. 169-197

Herndl, G. J. (1988). Ecology of amorphous aggregations (marine snow) in the Northern Adriatic Sea. II. Microbial density and activity in marine snow and its implication to overall pelagic processes. Mar. Ecol. Prog. Ser. 48: 265-275

Herndl, G. J., Peduzzi, P. (1989). Potential microbial utilization rates of sublittoral gastropod mucus trails. Limnol. Oceanogr. 34: 780-784

Herndl, G. J., Velimirov, B. (1986). Microheterotrophic utilization of mucus released by the Mediterranean coral Cladocora cespitosa. Mar. Biol. 90: 363-369

Hobbie, J. E., Daley, R. J., Jasper, S. (1977). Use of Nuclepore filters for counting bacteria by epifluorescence microscopy. Appl. environ. Microbiol. 33: 1225-1228

Hollibaugh, J. T., Azam, F. (1983). Microbial degradation of dissolved proteins in seawater. Limnol. Oceanogr. 28: $1104-1116$

Hoppe, H.-G. (1983). Significance of exoenzymatic activities in the ecology of brackish water measurements by means of methylumbelliferyl-substrates. Mar Ecol. Prog. Ser 11 299-308

This article was submitted to the editor
Hoppe, H.-G. Schramm, W. Bacolod, P. (1988). Spatial and temporal distribution of pelagic microorganisms and their proteolytic activity over a partly destroyed coral reef. Mar. Ecol. Prog. Ser. 44: 95-102

Horn, P. L. (1986). Energetics of Chiton pelliserpentis (Quoy \& Gaimard, 1835) (Mollusca: Polyplacophora) and the importance of mucus in its energy budget. J. exp. mar Biol. Ecol. 101. 119-141

Hylleberg, J. (1975). Selective feeding by Abarenicola pacifica with notes on Abarenicola vagabunda and a concept of gardening in lugworms. Ophelia 14: 113-117

Kirchman, D., Mitchell, R. (1982). Contribution of particlebound bacteria to total microheterotrophic activity in five ponds and two marshes. Appl. environ. Microbiol. 43: 200-209

Myklestad, S. M. (1978). Chemical composition, growth, and metabolism of some marine planktonic diatoms. Inst. of Mar. Biochemistry, Univ. of Trondheim, Report Nr. 35

Paine, R. T (1971). Energy flow in a natural population of the herbivorous gastropod Tegula funebralis. Limnol. Oceanogr 16: 86-98

Peduzzi, P. (1987). Dietary preferences and carbon absorption by two grazing gastropods, Gibbula umbilicaris (Linné) and Jujubinus striatus (Linné). P.S.Z.N.I: Mar. Ecol. 8: $359-370$

Peduzzi, P. (1990). Colonization and carbohydrate utilization of gastropod mucus (Monodonta turbinata) by microheterotrophs. Arch. Hydrobiol. Beih. Ergebn. Limnol. 34: 129

Peduzzi, P., Herndl, G. J. (1986). Role of bacteria in decomposition of faecal pellets egested by the epiphyte-grazing gastropod Gibbula umbilicaris. Mar. Biol. 92: 417-424

Peduzzi, P., Herndl, G. J. (1991). Decomposition and significance of seagrass leaf litter (Cymodocea nodosa) for the microbial food web in coastal waters (Gulf of Trieste, Northern Adnatic Sea). Mar. Ecol. Prog. Ser. 71 163-174

Priest, F. G. (1984). Extracellular enzymes. Van Nostrand Reinhold, Wokingham, p. 79

Reise, K. (1983). Biotic enrichment of intertidal sediments by experimental aggregates of the deposit-feeding bivalve Macoma balthica. Mar Ecol. Prog. Ser 12: 229-236

Rosso, A. L., Azam, F. (1987). Proteolytic activity in coastal oceanic waters: depth distribution and relationship to bacterial populations. Mar Ecol. Prog. Ser. 41: 231-240

Somville, M. (1984). Measurement and study of substrate specificity of exoglucosidase activity in eutrophic water. Appl. environ. Microbiol. 48: 1181-1185

Strickland, J. D. H., Parsons, T R. (1972). A practical handbook of seawater analysis. Bull. Fish. Res. Bd Can. 167

Vives Rego, J., Billen, G., Fontigny, A., Somville, M. (1985). Free and attached proteolytic activity in water environments. Mar. Ecol. Prog. Ser 21: 245-249

Wieser, W. Dalla Via, J. (1982). Scaling of gill size and leveis of. oxygen consumption in Monodonta turbinata (Born 1780). Mar Biol. Lett. 3: 335-343

Wright, J. R. Hartnoll, R. G. (1981). An energy budget for a population of the limpet Patella vulgata. J. mar biol. Ass. U.K. $61 \quad 627-646$

Manuscript first received: April 15, 1991

Revised version accepted: June 24, 1991 